Dorota Masłej (D) https://orcid.org/0000-0002-2037-1904

Adam Mickiewicz University, Poznań

dorota.maslej[at]amu.edu.pl

\title{
A Mediaeval Teaching Aid. An Analysis of One Page from the Manuscript by Jakub of Piotrków ${ }^{\star}$
}

\begin{abstract}
The purpose of this paper is to characterise page 190v of the manuscript preserved in the Jagiellonian Library (shelfmark 1297). The foregoing research has considered the page as a separate item, while the present study poses new questions concerning the writer's intention, the function of the page, and its possible status.

The main part of the paper is an attempt to reconstruct the sequence of writing the elements of the layout, or page composition, paying special attention to the relations between them. Reconstructing the probable sequence of writing the texts on the analysed page allows the proposal of a hypothesis of how the author (known as Jakub of Piotrków, the Canon of Płock) worked on it. The analysis shows that the author's intention could have changed as subsequent elements were being written on the page.

Certain elements of the page were selected for use depending on the audience of the lecture and its purpose. The latest research that linguistic relics like this one, closely bound up with orality of the mediaeval language, are not (were not) complete works in their final shapes, but rather texts in statu nascendi. The text discussed is
\end{abstract}

* Polish text: D. Masłej, "Średniowieczna pomoc dydaktyczna. Studium jednej karty z rękopisu Jakuba z Piotrkowa,” Terminus 2/17 (2015), pp. 219-240. 
an example of a genuine teaching aid that served the writer, Jakub of Piotrków, and probably later clergymen in ministering.

Keywords: macrostructure of a page, layout of prayers and commentaries, creative process, lecture in the Middle Ages, mnemonics, mediaeval teaching, Jakub of Piotrków, basic prayers and commentaries

In the Middle Ages, as it is known, the contemporary concept of the book did not exist. Usually, texts were written down on loose leaves or folios, which later-when bound-could take the form of a codex. This is why a single codex could contain many works and different texts not necessarily related to each other. ${ }^{1}$ The first or final pages of codices, sometimes also tip-ins in manuscripts, were often a special place where the user of the book wrote down texts or some extracts that he or she considered the most necessary (very often the last pages or tip-ins contain hand-written catechism prayers) or important information.

When describing a given historical-linguistic or literary problem, contemporary scholars analyse selected individual elements from both a codex and such tip-ins, while the remaining material is only mentioned. This is how the title page marked 190v from the manuscript of the Jagiellonian Library (shelfmark 1297) has been treated in the research to date. ${ }^{2}$ The codex discussed is one of twenty-five

1 See, among others, E. Potkowski, Ksiażka rękopiśmienna w kulturze Polski, Warsaw 1984, p. 83; W. Semkowicz, Paleografia łacińska, $3^{\text {rd }}$ edition, Cracow 2011, pp. 76-77, 115-119.

2 The codex was described by Alexander Brückner (see A. Brückner, "Kazania średniowieczne", part 1, Rozprawy Akademii Umiejętności. Wydział Filologiczny 24 (1895), pp. 70-77); its content has also been described by the authors of Katalog łacińskich rękopisów średniowiecznych Biblioteki Jagiellońskiej, see Catalogus codicum manuscriptorum medii aevi latinorum qui in Bibliotheca Jagellonica Cracoviae asservantur, vol. 8, ed. M. Kowalczyk et al., Cracow 2004, pp. 140-145. 
owned by the Canon of Płock, Jakub of Piotrków. ${ }^{3}$ It is known that he studied and worked in several places (Piotrków, Prague, Płock, Radzanów, Cracow), and his activity as a priest was not limited to the ordained ministry. He was also engaged in examining parish priests suspected of heresy. ${ }^{4}$ Although the manuscripts in the library of Jakub of Piotrków were not written by him, many of them contain his glosses or notes. The page discussed herein was one of many written entirely by him. ${ }^{5}$ This makes it unique against the backdrop of the vast majority of mediaeval texts, if only because we know by name the person who wrote down all the texts in it and is the author of the specifically composed whole.

In his description of the page, Alexander Brückner mentioned only: "among other things, the Latin and Polish texts of the prayers, Hail Mary and Creed, according to mediaeval tradition divided among the parting apostles; ... and the translation or justification of some phrases in the Polish prayers, added to their Latin text", ${ }^{\prime}$ while the very discussion of the commentary on the translation of the prayers took the form of an evaluation rather than a complete analysis. Later scholars, Wiesław Wydra and Wojciech Ryszard Rzepka, who dealt with the Polish text of the prayers and published a commentary on their translation, also barely mentioned other elements on the page. ${ }^{7}$ In Cezary K. Święcki's work, the only information given was (following his predecessors) that "on the penultimate page of the manuscript ... there were many different texts", ${ }^{8}$ of which only a part was

3 See M. Kowalczyk, E. Belcarzowa, and F. Wisłocka, "Glosy polskie Jakuba z Piotrkowa i innych autorów w rękopisach Biblioteki Jagiellońskiej”, Biuletyn Biblioteki Jagiellońskiej 1973, p. 85. For more information on the library of the Canon of Płock see also Potkowski, Książka, p. 180.

4 Ibid.

5 See ibid., p. 88; also Brückner, "Kazania".

6 Ibid., p. 76.

7 See W. R. Rzepka and W. Wydra, "Nota do dziejów ortografii staropolskiej", Slavia Occidentalis 31 (1974), p. 107.

8 C. K. Święcki, Kultura literacka Płocka $w$ średniowieczu, Warsaw-Siedlce 2006, p. 122. 
(sometimes erroneously) identified and mentioned. I also followed this lead, describing selected elements of the page and carrying out a detailed analysis of the metatextual and metalinguistic commentary to the Polish translation of prayers. ${ }^{9}$

Tomasz Mika recently postulated a different research procedure, which includes a comprehensive examination of manuscript folios. He mentioned the page under discussion as an example that requires such an analysis. He believes that it is an example of

... a spatial arrangement of catechism prayers (Our Father, Hail Mary, Decalogue, etc.) and comments to them, full of graphic and textual (including metalinguistic and metatextual) connections ... ${ }^{10}$

Treating this page as a whole allows the formulation of questions that cannot be posed when examining its individual elements:

Here, of course, there will be interesting detailed issues, such as what the intention of the creator of such a whole was or to whom it was addressed? Could the target reader use it selectively? If so, it may turn out that the function of the whole may have been different (lecture on prayers, their explanation, theological and translational remarks) than the function of the individual texts that constitute it (saying a given prayer with the faithful), but not all of the constituent texts may have functioned independently. Being clearly something more than the sum of the texts written on it, is such a page also a text? Where does it start and end? ${ }^{11}$

The aim of this paper is to answer these questions and formulate new ones. To this end, it is necessary to describe all the components that make up the page. It contains twelve elements distinguished by the scribe with a pilcrow or, in one case, a decorative initial. In the photograph, the individual components are framed and numbered (1-12).

9 D. Masłej, "O wyjątkowym średniowiecznym komentarzu do tłumaczenia modlitw”, LingVaria 2/20 (2015), pp. 221-234.

10 T. Mika, "Tekst staropolski jako odmienny obiekt badań? W poszukiwaniu narzędzi opisu”, LingVaria 2/20 (2015), pp. 235-250.

11 Ibid., p. 241. 


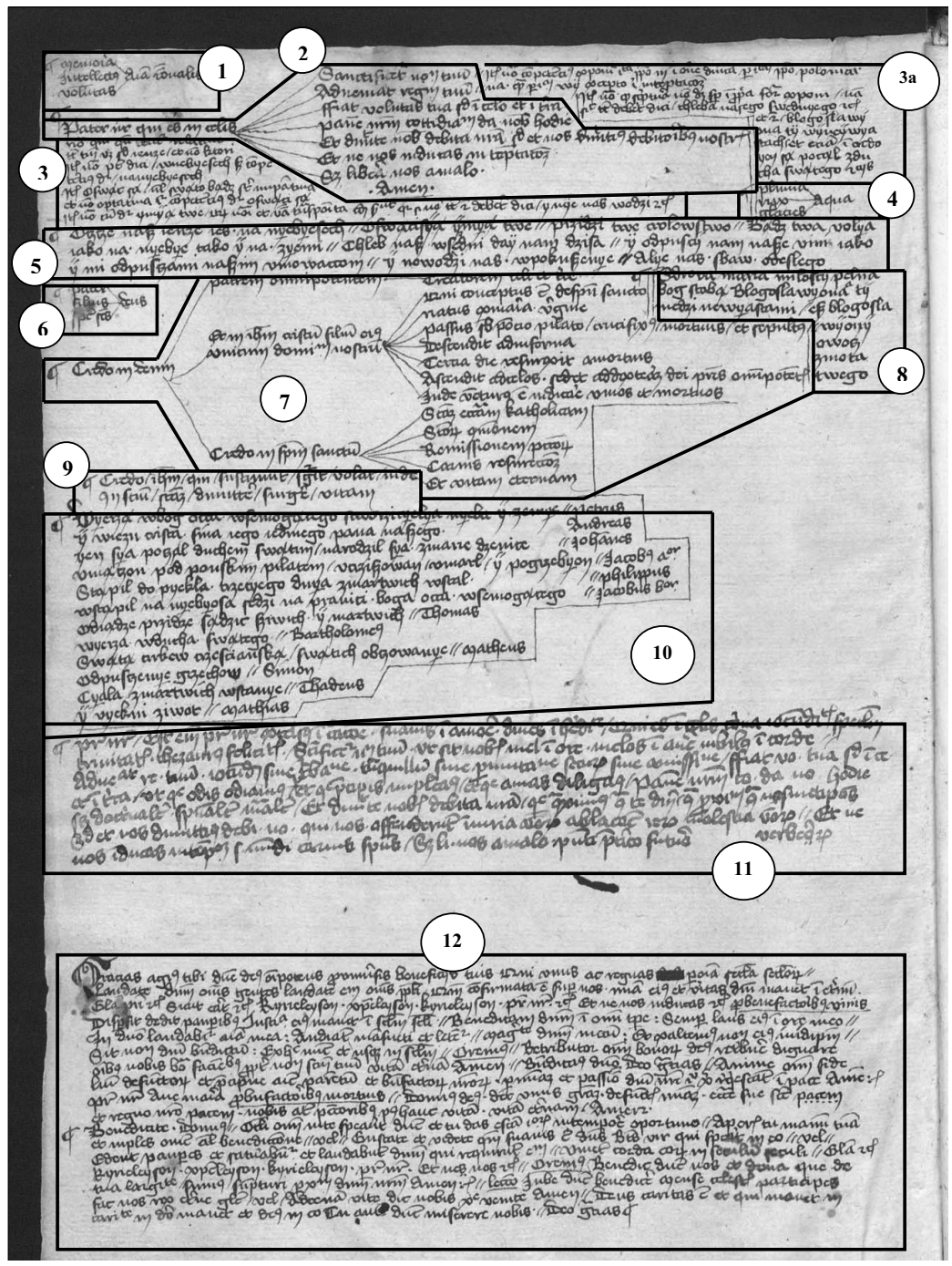

Illus. 1 Manuscript 1297, f. 190v, the Jagiellonian Library 
(1) A division of the "rational soul" (anima rationalis) ${ }^{12}$ into memory, intellect, and will (memoria, intellectus, voluntas), about which St Thomas Aquinas wrote that they are animae essentia, ${ }^{13}$ while St Augustine considers them to be the three powers of the soul.

(2) The text of Pater noster in Latin, divided into seven requests according to mediaeval tradition.

(3), (3a) Latin metatextual and metalinguistic commentary on the translation of the prayers into Polish. ${ }^{14}$

(4) A division of water (aqua) into various forms: rain, snow, and ice (pluvia, nix, glacies).

(5) The text of Our Father in Polish, written on the whole width of the page but divided into seven requests by the use of a delimitation sign (double slash); one of the oldest of the twenty-two preserved Polish copies of the Lord's Prayer. ${ }^{15}$

(6) A schematic division into three Divine Persons: the Father, the Son and the Holy Spirit (Deus-pater, filius, spiritus sanctus).

(7) The Latin text of Credo in Deum, according to tradition, divided into three parts that correspond with three Divine Persons and their individual qualities.

(8) The Polish text of Hail Mary (Sdrova maria miloscy pelna) in the original, so-called biblical form that functioned until the end of the fifteenth century, written on the margin of the Latin text of the Creed.

12 It is, according to St Thomas Aquinas, one of the three parts of the soul: "Sed tantum tres partes animae communiter ab omnibus assignantur, scilicet anima vegetabilis, anima sensibilis, et anima rationalis" (Summa 1, 78 a. 1 arg. 1).

13 "Et per hunc modum Augustinus dicit quod memoria, intelligentia et voluntas sunt una animae essentia" (Summa 1, 77 a. 1 ad 2).

${ }^{14}$ It was the only one to be published several times: Brückner, "Kazania", p. 76; Rzepka and Wydra, "Nota", pp. 116-117; W. R. Rzepka and W. Wydra, Chrestomatia staropolska, $3^{\text {rd }}$ edition, Wrocław 2004, p. 24, recently reedited and reissued: Masłej, "O wyjątkowym średniowiecznym".

${ }_{15}$ A list of all the texts: see D. Masłej, "Problem szyku w staropolskich przekładach Modlitwy Pańskiej”, Kwartalnik Językoznawczy 4 (2013), pp. 33-34, footnote 2. 
(9) A several-word-long abridgement of a prayer or lecture on the Creed, in which each word is separated by slashes (Credo/ihesum/ qui/sustinuit).

(10) The text of the Creed in Polish, divided into lines in a way almost entirely consistent with the Latin division (if two Latin lines are written in one line in the Polish text, as happens twice, they are separated by a single slash; a slash also appears in those places where it was used in the Latin text). The names of the apostles were added to the individual passages. ${ }^{16}$

(11) The paraphrase of Our Father by Ludolph of Saxony. The text comes from the work of Vita Christi (Chapter XXXVII: Sermonis in monte continuatio) and is preceded by a theological lecture on Pater noster. ${ }^{17}$

16 Brückner writes that Credo is "divided according to medieval tradition among the parting apostles", Brückner, "Kazania", p. 76. The history of this tradition is explained in detail by Wojciechowski: "Before they parted, in order not to lose unity in the faith, the Apostles arranged, under the inspiration of the Holy Spirit, an indicator, an outline (indicium) of what they were to preach; each of the Twelve contributed to it and hence it is called the Symbol of the Apostles (collatio) ... In the sixth century, the relationship between the Twelve and the Symbol was clarified and each of them was assigned a specific article. This division was later presented many times in literary and iconographic forms. However, parts of the Symbol were not always connected with the same persons (although Peter invariably spoke the first article). The content arranged in such an order became the basis for the liturgical commemoration of divisionis Apostolarum", L. Wojciechowski, "Treści ideowe święta Rozesłania Apostołów w Polsce średniowiecznej. Zarys problematyki”, in: Symbol apostolski w nauczaniu i sztuce Kościoła do Soboru Trydenckiego, ed. R. Kapuściński, Lublin 1997, pp. 311-312. Although scholars speak of a certain tradition, there are many records of catechism prayers that do not follow it. This may be due to the purpose of the specific records, which will be discussed later.

17 On the work of Ludolph of Saxony see K. Bielawski, "Ludolf z Saksonii i jego dzieło", Terminus 1-2 (2002), pp. 229-257, here also a translation of the prayer based on the requests contained in Our Father. Krzysztof Bielawski stated that "the work of the Carthusian [Ludolph of Saxony] was little known in Poland" (p. 235). However, the fact that a fragment of Vita Jesu Christi has been identified on the page that was supposed to be used, among other things, for the teaching of prayers, seems to contradict this thesis. A quick look at the two editions of the paraphrase 
(12) The text of Benedictiones mensae (prayers before and after a meal): Post prandium, from the next paragraph: Ante prandium.

Having presented the content of the whole page, I would like to try to reconstruct the sequence in which the texts were written (and thus the page was composed), focusing in particular on the relations between the individual elements. The belief that the page was originally intended by the author to look different is supported by, among other things, the place and manner in which the commentary on the translation of the prayers was written $(3,3 \mathrm{a})$. If the Latin and Polish texts of Our Father had been written with the intention of adding a comment to them, this treatise would have been written in its entirety in a planned location. However, it was written in two different places on the page, divided into parts resulting from the lack of free space, without any substantive or logical justification. The comment is simply put near the text of the Lord's Prayer. Therefore, it creates a graphical frame for Pater noster (see Fig. 1, elements: 2, 3 and 3a).

This observation makes it possible not only to recreate the hypothetical sequence of writing, i.e. the creative process of Jakub of Piotrków, but also to ask a question about the function of the analysed

allows us to state that the prayer written on folio 190v of the BJ 1297 manuscript is another variant of the text, which probably functioned in many copies and in many different versions (see the following edition: Vita Jesu Christi e quatuor evangeliis et scriptoribus orthodoxis concinnata per Ludolphum de Saxonia ex ordine carthusianorum, editio novissima studio et opere A. C. Bolard, L. M. Rigollot, and J. Carnandet, Parisus-Romae 1865, p. 168; "Paraphrase of the Lord's Prayer by Henry William Ludolph of Germany", The Litterary World. A Journal of Science, Literature and Art 8/224 (1851), p. 401. It is also worth noting that in the manuscript from Czacki's collection ( I Q 199) Alexander Brückner found an "explanation of the prayers" with annotations (see A. Brückner, "Drobne zabytki języka polskiego XV wieku. Pieśni. Modlitwy. Glosy", Rozprawy Akademii Umiejętności. Wydział Filologiczny 2/10 (1897), p. 271, which, although not identified by Brückner, is yet another variant of this text by Ludolph of Saxony (see D. Masłej, "O zapomnianym polskim tłumaczeniu tzw. Parafrazy Modlitwy Pańskiej Ludolfa z Saksonii”, Poznańskie Spotkania Językoznawcze 33 (2017), pp. 57-66). The fact that it was annotated allow us to conclude that Vita Jesu Christi or at least this part of the work was known and used in mediaeval Poland. 
page, which could have changed over time when the author worked on the texts. I have distinguished three hypothetical stages of the author's work on the page.

Polish and Latin texts of Pater noster and Credo $(2,5,7,10)$ were probably the first to appear on the page, which is shown in the photograph prepared for the purpose of this analysis (see Fig. 2).

Figure 2 shows a clearly repetitive arrangement: the Latin prayer text divided according to tradition and its translation into Polish. One can also see the natural order of working with an empty page, such as aligned section signs that begin the texts or white spaces between texts that are similar. The page, therefore, resembles other collections of catechism prayers known from mediaeval artefacts, although even in this form, it is not fully convergent with them. The difference lies in the presence of a Latin text (among the surviving artefacts of this type, Polish texts was preceded by their Latin counterparts only in one manuscript ${ }^{18}$ ) and the way the text area was shaped, as well as in the absence of the third catechism prayer, that is Hail Mary. These discrepancies allow us to state that the original function of the sheet, as in the case of the catechism prayer collections, was not to create a specific "compendium" or a handy catechism. The graphic shape of text areas of Latin prayers and the attempt to reflect the abovementioned divisions in the Polish texts (by means of delimitation signs and-in the case of Credo-division into lines ${ }^{19}$ ) indicates that the original function of the analysed page was not so much to aid prayers, but rather to lecture on them (which was done traditionally by basing a lecture on the division of prayers into strictly defined parts ${ }^{20}$ ) or to memorise them, which can be evidenced by assigning

18 Manuscript 3729 in the Czartoryski Library in Cracow.

19 In the case of mediaeval texts, written mainly in continuo, this was not without significance.

20 Jerzy Wolny discussed this question in his "Z dziejów katechezy", in: Dzieje teologii katolickiej w Polsce, vol. 1: Średniowiecze, ed. M. Rechowicz, Lublin 1974, pp. $181 \mathrm{ff}$. 


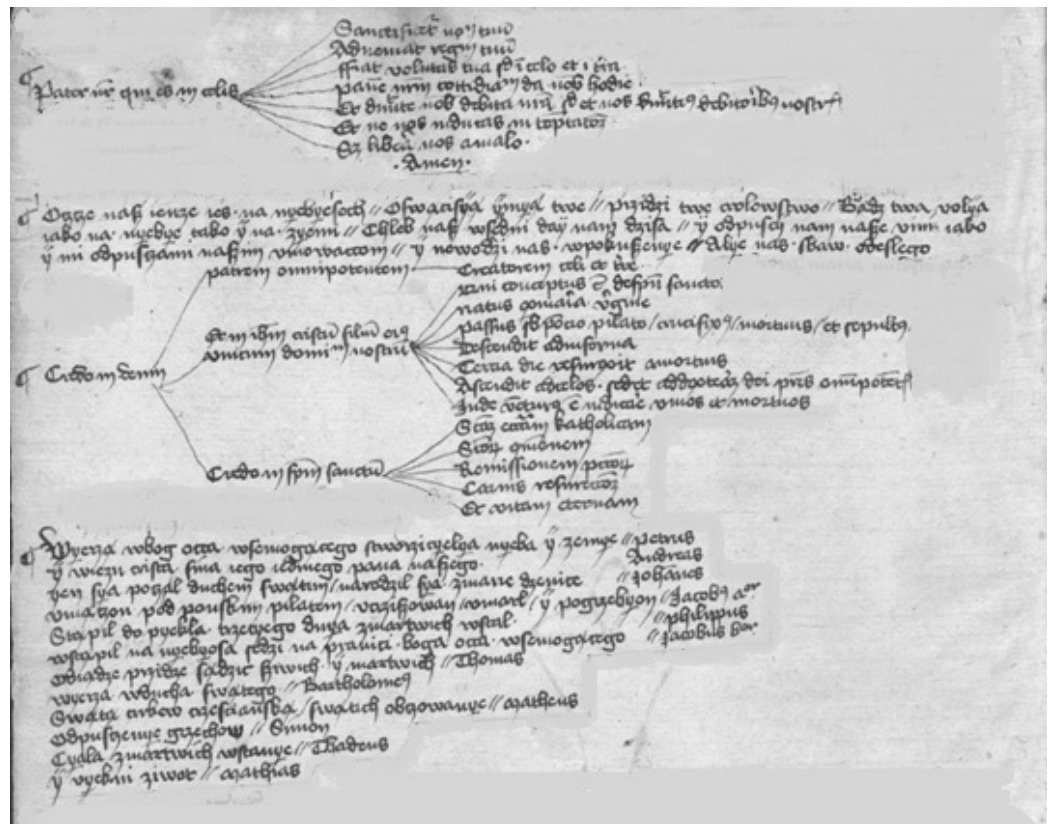

Illus. 2. Manuscript 1297, f. 190v, the Jagiellonian Library-a hypothetical first stage of the writer's work

the names of apostles to particular fragments of the Creed. ${ }^{21}$ However, it is not known who was to be the audience of such a lecture. It

21 Brygida Kürbis writes about the Clm 22053 codex: "The second theme includes elementary information about faith and morality ... all of them summed up in short sentences and arranged in sets of three, four, seven and eight, at most twelve, which served evidently learning by heart at school. A more widely known teaching method was to divide the Creed among the twelve Apostles. The Creed appears twice in this codex, and the variant with the Apostles is the second one. Elementary catechesis, supported by mnemonics for remembering numbers and which by this practical way easily became an allegorical exegesis, was characteristic for Celtic-Christian circles [emphasis-D.M.]", B. Kürbis, "Szkoła i katecheza według rękopisu z Wessobrunn (München, Clm 22053, ok. 800 r.)”, Studia Źródłoznawcze 35 (1994), p. 10. 
is very likely to have been intended for the faithful present at Mass because often explanations of prayers were given instead of sermons based on Scripture. ${ }^{22}$ But it could as well be listened to by the clergy or future clergy, who prepared themselves for the role of preachers, as-according to Jerzy Wolny-the recommendations of the synods were clear in this respect:

Archbishop Jakub recommends that bishops or their delegates teach the clergy during synods about the sacraments and the Creed so that the clergy can understand the teaching material clearly. Nanker also writes that priests should know the articles of faith, Pater noster and Ave Maria. St Thomas examines the question of whether everyone is obliged to have explicit faith [Lat. fide explicita, faith based on the knowledge of divine truth-K. S.]. According to St Thomas, only those who teach others are obliged to have such a knowledge of faith. The influence of St Thomas is evident both in the canon that belonged to Archbishop Jakub and Bishop Nanker. The clergy as teachers ex officio had to know the exegesis of the Credo, Pater noster, and Ave Maria. ${ }^{23}$

These four basic elements on the page are obviously interrelated. On the one hand, Pater noster and Ojcze nasz (Our Father), as well as the Credo and Wyznanie wiary (the Creed), are in fact two texts written in Latin and Polish; on the other hand, these basic catechism prayers very often appeared together as the two most important texts of Christianity. The function of the sheet in its presumable original form was, therefore, most probably to teach or lecture on the Lord's Prayer and the Creed. Texts marked 1, 3, 3a, 4, 6, 8, 9, and 11, in my opinion, were not originally (i.e. at the first stage of creating and using the page) intended by the author to be included on the page, but

22 Sczaniecki calls such a lecture "a catechetical sermon referring to the Creed", P. Sczaniecki, Stużba boża w dawnej Polsce, Poznań 1962, p. 78; Wolny also writes about it, drawing attention to the existence of "treatises for teaching the faithful, in fact, textbooks for clergy for parish teaching. These include the texts explaining Pater noster, the Credo, the Decalogue... They were often written on the last pages of manuscripts", Wolny, "Z dziejów", p. 190.

23 Ibid., p. 192. 
directly result from the function of its reconstructed original form (lecture, explanation of prayers).

In order to explain the Creed, a preacher had to elucidate to the listeners the essence of the Holy Trinity first. Hence, as one may suppose, the separate description of the three Divine Persons (6). Explaining this dogma was certainly very difficult. Perhaps metaphors were used to explain the unity of God's nature in three forms. In another part of the page (4), the division of water into three forms was presented: pluvia, nix, and glacies. Comparing God and the three Divine Persons to water and its three states could be a preaching device. ${ }^{24}$ It is worth noting that both these components of the page are graphically very similar to each other. It should also be pointed out that the relationship between these elements of the page is two-step. The initial text, which is the reason for all the subsequent additions, is the Polish and Latin version of the Credo, but one can easily imagine that it was a direct impulse only for the scheme marked with number 6 (the three Divine Persons), and this one triggered the next (4-the three states of water). In such a case, there would be no simple relationship between the text of the Creed and the schematic division into three forms of water.

24 If we consider this hypothesis to be correct, it is worth noting that the likely recipient of the lecture was the people, as Rafał Wójcik writes: "Preachers were commanded to apply in their sermons for the commonalty the division of the theme on the basis of the extra, that is from the outside. The extra was supposed to be based on sensual and material images taken from the visible world, which the people could imagine and remember at any moment. On the other hand, sermons for clergymen, i.e. literate people who were conversant with abstract concepts, were to be divided according to the intra principle, i.e. they were to be strictly doctrinal lectures based on abstract reasoning"; "[Giovanni di San Gimignano's recommendations] could be summarised as follows: in sermons various things should be presented in the form of extraordinary similarities because, unlike spiritual concepts, such images will be much better remembered by listeners", R. Wójcik, Opusculum de arte memorativa Jana Szklarka. Bernardyński traktat mnemotechniczny z 1504 r., Poznań 2006, pp. 34, 37. 
The "three features of the soul", namely memory, intellect and will listed at the top of the page, should also be associated with the explanation of the dogma as "the first remembers what the second understands and the third wishes; the second understands what the first remembers and the third wishes; the third wishes what the first remembers and the second understands". ${ }^{25}$ As Rafał Wójcik remarked:

St Augustine wrote that the three features of the human soul are a reflection of the Holy Trinity in man. Intellectus, or reason, allows us to know or approach the truth, voluntas, or will, is the art of practising the will to love the truth, memoria, or memory, is an art that allows the truth to be remembered. ${ }^{26}$

Probably the note marked 9 was also used to explain the Credo as it is to some extent an abridged version of it. Following the initial part of the profession of faith (Creed/Ihesum), the author mentions almost all the verbs associated with Christ's passion, death and resurrection (sustinuit, surgit, volat, dimittere, surgere), all separated by slashes. This could be used for mnemonic purposes. ${ }^{27}$

The commentary on the translation of prayers into Polish $(3,3 \mathrm{a})$ and the paraphrase of the Lord's Prayer by Ludolph of Saxony (11) is connected with the daily work on the text of Pater noster. The

25 F. A. Yates, Sztuka pamięci, transl. W. Radwański, Warsaw 1977, p. 187.

26 Wójcik, Opusculum, p. 36. Such teaching of the essence of the three Divine Persons can in turn be considered as a lecture based on abstract reasoning, and thus intended for clergy.

27 In his treatise De arte memorativa, Jan Szklarek recommends memorising specific lex verba (expressions) as one of the ways of committing to memory a sermon or history: "Septima cautela historiarum, sub qua erit cautela sermonum, quia eam historiam aut volumus, ut recordetur solum, aut etiam, ut dilatetur, vel tercio, ut predicetur. Exemplum primi pro recordatione historie interfectionis sancti Stanislai videbuntur lex verba... [The seventh means that ensures we remember a story right, which shall also help memorising a sermon, whether we only want to commit the story to memory or to lecture or preach about it. The example of the first case: to memorise the history of the murder of St Stanislaus, we will take the following phrases as a principle...]", ibid., pp. 174-175. 
commentary on the translation of prayers could not be used without the texts it concerns (above all, without the text of Our Father, which is the source of the majority of examples discussed in the commentary). In this sense, it is not an independent text, ${ }^{28}$ although at the same time, it forms a frame of another text, which is independent but functions as if it was otherwise, as it is divided into fragments. One may surmise that it is because of this comment that the Polish text of Hail Mary (8) appeared on the page as well. In the entire commentary, which discusses several problems (such as the manner of translating the Latin preposition in in the text of prayers, the word order of the pronoun modifier, and other such questions ${ }^{29}$ ), examples from the Lord's Prayer and-at the end of the text-also from the Creed and Hail Mary are quoted: "Item nota quod scriptura non debet semper in propria forma exponi / nam sicut tunc deberet dici / chleba nasego swednyego etc. et etiam / blogoslawyona ty wyneywyastach / et etiam in credo yen są pocąl zducha swątego et aliis". I suppose that the author, having written a commentary on the translation of prayers, added in the margin a version of Hail Mary known to him that in his opinion was the only correct one, perhaps in order to be able to easily refer to the proper form of the prayer during a lecture (in this fragment of the commentary the writer mentions versions that are incorrect in his opinion).$^{30}$ It is worth noting that in the light of the proposed chronology of the writing of the texts, the relations between them are again becoming two-tier. The text of

28 This is also evidenced by the fact that the comment is the only element in the upper part of the page not distinguished by a separate paragraph. The beginning of the commentary is worth a bit of attention. It is not located, in the place where the words nota qui quando are written, as indicated in Figure 1, but higher up. The beginning of the commentary is the first line of Pater noster, not repeated in the text of the lecture, but-once written-it belongs simultaneously to two texts on the page: the prayer ("Pater noster qui es in celis / Sanctificetur nomen tuum...") and the metatextual commentary ("Pater noster qui es in celis / nota qui quando tenetur relative...").

29 For more information see Masłej, "O wyjątkowym średniowiecznym”.

30 For a detailed analysis of this passage, see ibid. 
the Lord's Prayer written in Latin and Polish became an inspiration to add a commentary, which may have resulted in adding the third catechism prayer to the page. This one is clearly less important in the whole composition - the place and manner in which it is written (e.g. without the Latin text) allow us to state with certainty that it was not added at the first stage of composing the page.

The paraphrase of the Lord's Prayer by Ludolph of Saxony (11), which is a free interpretation and continuation of Our Father, is directly connected with the text of Pater noster. Krzysztof Bielawski writes that:

... with all its educative value, Vita Christi is, according to the author's intention, primarily a spiritual work, a prayer. Its main purpose is to aid one's spiritual life, one's inner progress on the way to God. It is simply a great prayer book, probably the biggest one ever written. It can also be called a practical textbook for prayer and meditation. ${ }^{31}$

This is certainly also the purpose of the fragment of this impressive work written on folio 190v. It was not chosen by accident as it is closely connected with the second central text on the page.

The last text to be written on the page was the one marked 12, i.e. Benedictiones mensae. Prayers before and after meals are graphically severalised from the previously discussed part of the page by white space that separates it from other texts. This text was also distinguished by the author of the composition with a much larger and more ornate initial, as well as by the lack of pilcrow, ${ }^{32}$ which marks

31 Bielawski, "Ludolf z Saksonii", p. 234.

32 This, however, appears on the margin and separates the two parts of Benedictiones mensae-it indicates the place where Post prandium ends and Ante prandium begins. It should be noted that the knowledge about the author is very helpful in reproducing the hypothetical purposes for which the page could have been used. Not only do we know the facts of Jakub's life and his functions, but we can also identify the manuscripts that he possessed. In this way we know, for example, that book collection included a manuscript (BJ 1356) with fragments from Compendium theologicae veritatis by the Dominican Hugo Ripelin de Argentina, about which 
individual elements in the upper part of the page. Although in the text of prayers we can rightly search for links with the text of Our Father (saying Pater noster is one of the parts of Benedictiones mensae, and its parts appear in the fragment discussed), it seems that this text-both in terms of its purpose and because of its graphic distinction-does not relate to the other elements on the page. This may suggest that the author wrote it down later, making use of the free space on the page (just in case, however, he left some free room above it). It should be noted that the page is not a complete entity. This is evidenced by free spaces separated from the written parts by bars. Lines are used to separate the texts on the page (the line between the second part of the comment (3a) and the Pater noster (2), as well as between the Angelic Salutation (8) and the Credo (7)). The delineated empty space to the right from the Latin and Polish texts of the Creed proves that the writer was considering the possibility of adding further texts useful to him in his work. This, in turn, confirms the hypothesis of the gradual creation of the artefact, which at the very beginning was not a whole composed in the form that has survived to this day.

With the above knowledge about the discussed folio, we should now return to the questions posed at the beginning of this paper. The research procedure adopted (reconstructing the order of the texts written on the page) allows the reconstruction of the probable sequence of stages in which the sheet was created. It also permits questions about the intention of the author, the functions of the page at each stage of its creation, and its functions as a macrostructure.

Jerzy Wolny wrote: "The manuscripts of the Cracow professors include numerous treatises on theological literature. The presence of these treatises resulted from the educational needs of their owners. Particularly useful were the treatises that had the character of a textbook, among which the best known was Compendium theologicae veritatis by Hugo Ripelin de Argentina, a Dominican”, Wolny, “Z dziejów”, p. 199. This bears testimony to the author's preparation for preaching catechetical sermons and for acting in the capacity of a lecturer, just as the fact that on the margins of many of his manuscripts there are comments to the Bible, mnemotechnical formulations, small poems (see Kowalczyk, Belcarzowa, and Wisłocka, "Glosy", p. 87). 
As the foregoing analysis has shown, the intention of the author could have changed with the writing of subsequent elements. At first, the page could have served as an aid for a theological lecture. It is plausible that although it was not initially supposed to help in reciting the prayers from the very beginning, it could be used to teach prayers, as well as to learn by heart both Polish and Latin texts. The audience could be the faithful (as an aid in teaching basic Christian prayers in Polish), but also clerics who prepared to serve in parishes (texts of prayers in Polish and Latin). At the second stage, the functions of the page are clearly focused on elucidating the truths of faith and explaining the texts in terms of theology as well as language (metatextual and metalinguistic commentary on the translation of prayers into Polish). This, in turn, suggests that the supposed audience included not only the commonalty (this type of target audience excludes the use of some components of the page), but also clergymen or clerics preparing for the priesthood, people who were supposed to work with texts (in two language versions) and understand them thoroughly.

The user of the page (probably its author, Jakub of Piotrków, himself) certainly used it selectively. It is (except for part 12) a collection of various elements, texts and diagrams. The function of the whole was to help in the construction of a text, which for different purposes took on different forms. To write a lecture or sermon, the user of the page selected from among the elements those that he needed at the moment. He chose them according to the target audience of his speech and his objective (a sermon on catechism prayers and basic truths of faith, teaching prayers by means of mnemonic techniques, lectures for seminarians, examinations of priests ${ }^{33}$ ). This shows that the page as a whole could have different functions depending on the need. Interestingly, also those elements of the page that function independently of it (prayers), in this particular setting and in this form cease to fulfil the function usually attributed to written collections of prayers (compendium, catechism, recitation with the faithful).

The question formulated by Tomasz Mika, whether such a page is not only a collection of texts, but also a text in itself, is yet most difficult to answer in a comprehensive and unequivocal way. In the light 
of everything that has been said recently about the specificity and diversity of the old-Polish text, ${ }^{33}$ it is probably appropriate to conclude that such artefacts not so much are (were) but rather become (became) texts. The performance of texts aloud in various sender-receiver combinations allowed the user to choose from this set of components and create new and different wholes, ${ }^{34}$ complete texts presented in specific communication situations, with a beginning and an end, a specific intention, sender and receiver. ${ }^{35}$ Therefore, there is no single answer to the question about the beginning and end of this macrostructure.

The problem of the beginning and end of a text can also be treated in terms of issues related to its specific, individual components. The first line of Pater noster, once written, functions on the page as a potential beginning of two different texts (see footnote 28) - the choice was made on an ad hoc basis.

These findings should be viewed in the light of the orality of mediaeval culture. As Alain de Libera rightly wrote:

33 Cf. T. Mika, "Kazania świętokrzyskie jako obiekt badań filologicznych. Pytania o tekst i przekaz”, Z Badań nad Książką i Księgozbiorami Historycznymi 4 (2010), pp. 65-80; T. Mika, “Genetyczna wielowarstwowość i złożoność tekstów staropolskich a ich badania historycznojęzykowe. Rekonesans”, Biuletyn Polskiego Towarzystwa Językoznawczego 68 (2013), pp. 131-145; T. Mika, "Problemy z Rozmyślaniem przemyskim. Formułowanie sądów ogólnych a wielowarstwowość średniowiecznego tekstu”, LingVaria special issue (2015), pp. 87-104; Mika, “Tekst”.

34 This is a different situation from the one we know from our research on mediaeval sermons. According to the literature on the subject, sermons also became texts only when read aloud. It was due to the fact that only the template that the preacher filled out while preaching had been written down beforehand (see e.g. Sermon II from the collection of The Holy Cross Sermons, about which Marek Skwara wrote: "The Sermon, as it has survived, is a kind of model, an outline intended for specific, that is above all oral, performance", M. Skwara, "Struktura i sposoby argumentacji w Kazaniu na dzień św. Katarzyny", in: Kazania świętokrzyskie. Nowa edycja. Nowe propozycje badawcze, ed. P. Stępień, Warsaw 2009, p. 164). There is no outline here that needs to be filled with appropriate components. Rather there are components that need to be composed into a specific whole.

${ }_{35}$ On referring textuality determinants to mediaeval texts see Mika, "Tekst". 
... the textuality of the Middle Ages is ... if one can use such a term, oral textuality, and the mediaeval text is a combination of speech and writing; determining the proportions of these components in this mixture is sometimes impossible for the contemporary reader, and almost always very difficult. ${ }^{36}$

In the case of the page in question, which is a set of many texts and diagrams, that - as the presented analyses show-served to build coherent statements, it is clear that the "written components" contained only a small portion of what was to be said. De Libera further noted that in the Middle Ages the text:

. . . is rarely autonomous. Instead, it is supposed to support memory, which complements it, gives it meaning. Actually, that meaning is available only to memory. In most cases, the text does not allow for confidentiality. It exists almost exclusively for its user: a concise summary of what one said or heard ... a sketch of what one will say, a draft of a sermon, or a collatio (lecture). Although we have a warp, we lack not only the weave, but also the threads that could form the actual fabric. ${ }^{37}$

On sheets similar to the discussed title page, when an attempt is made to look at them as a whole, one can clearly see-using Libera's metaphor-only threads whose weave is and will remain unattainable for us, since it was created only when performed aloud. The artefact under discussion is an example of authentic teaching aid, which certainly served Jakub of Piotrków, and after him perhaps other preachers, in their priestly work.

Translated from Polish by Kaja Szymańska

36 A. de Libera, "Od lektury do parafrazy. Uwagi o cytacie w średniowieczu", transl. W. Maczkowski, Pamiętnik Literacki 79/2 (1988), p. 332.

37 Ibid., pp. 331-332. 


\section{Bibliography}

Bielawski, K., "Ludolf z Saksonii i jego dzieło", Terminus 1-2 (2002), pp. 229-257. Brückner, A., "Kazania średniowieczne”, part 1, Rozprawy Akademii Umiejętności. Wydziat Filologiczny 24 (1895).

Brückner, A., "Drobne zabytki języka polskiego XV wieku. Pieśni. Modlitwy. Glosy", Rozprawy Akademii Umiejętności. Wydział Filologiczny 2/10 (1897).

Catalogus codicum manuscriptorum medii aevi latinorum qui in Bibliotheca Jagellonica Cracoviae asservantur, vol. 8, ed. M. Kowalczyk et al., Cracow 2004. Kowalczyk, M., Belcarzowa, E., and Wisłocka, F., "Glosy polskie Jakuba z Piotrkowa i innych autorów w rękopisach Biblioteki Jagiellońskiej”, Biuletyn Biblioteki Jagiellońskiej (1973), pp. 79-115.

Kürbis, B., "Szkoła i katecheza według rękopisu z Wessobrunn (München, Clm 22053, ok. 800 r.)”, Studia Źródłoznawcze 35 (1994), pp. 10-22.

Libera, A. de, "Od lektury do parafrazy. Uwagi o cytacie w średniowieczu", transl. W. Maczkowski, Pamiętnik Literacki 79/2 (1988), pp. 331-344.

Masłej, D., "O zapomnianym polskim tłumaczeniu tzw. Parafrazy Modlitwy Pańskiej Ludolfa z Saksonii”, Poznańskie Spotkania Językoznawcze 33 (2017), pp. 57-66.

Masłej, D., "Problem szyku w staropolskich przekładach Modlitwy Pańskiej", Kwartalnik Językoznawczy 4 (2013), pp. 33-43.

Masłej, D., "O wyjątkowym średniowiecznym komentarzu do tłumaczenia modlitw”, LingVaria 2/20 (2015), pp. 221-234.

Mika, T., "Kazania świętokrzyskie jako obiekt badań filologicznych. Pytania o tekst i przekaz”, Z Badań nad Książką i Księgozbiorami Historycznymi 4 (2010), pp. 65-80.

Mika, T., "Genetyczna wielowarstwowość i złożoność tekstów staropolskich a ich badania historycznojęzykowe. Rekonesans”, Biuletyn Polskiego Towarzystwa Językoznawczego 68 (2013), pp. 131-145.

Mika, T., "Problemy z Rozmyślaniem przemyskim. Formułowanie sądów ogólnych a wielowarstwowość średniowiecznego tekstu", LingVaria special issue (2015), pp. 87-104.

Mika, T., "Tekst staropolski jako odmienny obiekt badań? W poszukiwaniu narzędzi opisu", LingVaria 2/20 (2015), pp. 235-250.

"Paraphrase of the Lord's Prayer by Henry William Ludolph of Germany", The Litterary World. A Journal of Science, Literature and Art 8/224 (1851).

Potkowski, E., Książka rękopiśmienna w kulturze Polski, Warsaw 1984.

Rzepka, W. R. and Wydra, W., Chrestomatia staropolska, $3^{\text {rd }}$ edition, Wrocław 2004.

Rzepka, W. R. and Wydra, W., "Nota do dziejów ortografii staropolskiej", Slavia Occidentalis 31 (1974), pp. 107-118.

Sczaniecki, P., Służba boża w dawnej Polsce, Poznań 1962.

Semkowicz, W., Paleografia łacińska, $3^{\text {rd }}$ edition, Cracow 2011. 
Skwara, M., "Struktura i sposoby argumentacji w Kazaniu na dzień św. Katarzyny", in: Kazania świętokrzyskie. Nowa edycja. Nowe propozycje badawcze, ed. P. Stępień, Warsaw 2009, pp. 153-166.

Święcki, C. K., Kultura literacka Płocka w średniowieczu, Warsaw-Siedlce 2006.

Vita Jesu Christi e quatuor evangeliis et scriptoribus orthodoxis concinnata per Ludolphum de Saxonia ex ordine carthusianorum, editio novissima studio et opere A. C. Bolard, L. M. Rigollot, and J. Carnandet, Parisus-Romae 1865.

Wojciechowski, L., "Treści ideowe święta Rozesłania Apostołów w Polsce średniowiecznej. Zarys problematyki", in: Symbol apostolski w nauczaniu i sztuce Kościoła do Soboru Trydenckiego, ed. R. Kapuściński, Lublin 1997, pp. 307-330.

Wolny, J., "Z dziejów katechezy”, in: Dzieje teologii katolickiej w Polsce, vol. 1: Średniowiecze, ed. M. Rechowicz, Lublin 1974, pp. 149-209.

Wójcik, R., Opusculum de arte memorativa Jana Szklarka. Bernardyński traktat mnemotechniczny z 1504 r., Poznań 2006.

Yates, F. A., Sztuka pamięci, transl. W. Radwański, Warsaw 1977. 
